\title{
Thermal Behaviour Analysis of Baffled Multi Heat pipe Induced Heat Exchanger
}

\author{
P. Ram Kumar, M.Sivasubramanian, P.RajeshKanna, P.Raveendiran
}

\begin{abstract}
Thermal behaviour of a multi-heat pipe induced in compact heat exchanger has been analysed with the influence of baffles. The heat transfer fluid and working fluid used for the investigation are water and acetone. In this investigation, baffles are used to improve performance. In this research, different parameters like temperature range of hot and cold water were $50^{\circ} \mathrm{C}, 60^{\circ} \mathrm{C}, 70^{\circ} \mathrm{C}$ and $32^{\circ} \mathrm{C}$ throughout the analysis. The mass flow rates of hot and cold water ranges as $40 \mathrm{LPH}$ to $120 \mathrm{LPH}$ and 20 $\mathrm{LPH}$ to $60 \mathrm{LPH}$ with an increase of $20 \mathrm{LPH}$ and $10 \mathrm{LPH}$. The result shows that for an optimum revealed conditions of an angle of $0^{\circ}$ with $60^{\circ} \mathrm{C}$ and $100 \mathrm{LPH}$ there is an increase in effectiveness occurs as $82.05 \%$ while comparing to without baffled conditions.

Keywords : Heat pipe, Heat exchanger, Mass flow rate, Effectiveness, Baffles.
\end{abstract}

\section{INTRODUCTION}

In several processing plant, heat recovery systems, space applications heat transfer performance in widely achieved using heat pipe. The performance of the heat pipe is analysed with different working fluids and fill ratios for space applications [1-2]. The heat pipe is analysed with gravitational effect shows superior in results with flat heat pipe [3-4]. Joudi and Witwit [5] analysed the wickless heat pipe with tilt angle effect, which shows improvement in performance. Hossain et al. [6] analysed the performance which depends upon various angles and different heat input does not depend on coolant flow rate. The study shows that for the similar input of heat and angle with acetone for micro heat pipe shows improved performance. Influence of working fluid for heat pipe was studied with several tested were stated in [7 -8]. Luis Diego Fonseca et al. [9] reveals with varying the working fluid with different fill ratios within $20 \%$ to $90 \%$, the optimal performance at a fluid ratio were $69.68 \%$. Shabgard et al. [10] applied a model on thermal network to characterize the thermal study in a high temperature latent heat thermal energy storage system.

The heat pipe with different materials and tilt angles were analysed with the wick of the heat pipe were reported [11-12]. Heat pipe with various working fluids and filling ratios were investigated for various applications revealed in

Revised Manuscript Received on December 05, 2019.

* Correspondence Author

P. RamKumar *, Department of Mechanical Engineering, Kalasalingam Academy of Research and Education, Krishnankoil, Virudhunagar, 626126, Tamil Nadu, India. Email: rkmailmech@gmail.com

M.Sivasubramanian, Department of Automobile Engineering, Kalasalingam Academy of Research and Education, Krishnankoil, Virudhunagar, 626126, Tamil Nadu, India. Email: m.sivasubramanian@klu.ac.in

P.RajeshKanna, Department of Mechanical Engineering, Al Ghurair University, Dubai, United Arab Emirates. Email: prkanna@gmail.com

P.Raveendiran, Department of Mechanical Engineering, Alagappa Chettiar Government College of Engineering and Technology, Alagappa University, Karaikudi - 630003, Tamil Nadu, India. Email: praveendiran@gmail.com
[13-14]. Vivek [15] fabricated a heat pipe using ammonia and methanol. The investigation were made on satellite applications and performance is analysed.

In the work of several researchers, their research was done with minimum geometrical constraints on heat pipe heat exchanger. The constraints includes were geometrical parameters, working fluids, fill ratios and heat transfer fluids in heat pipe. To rectify the above-stated constraints in this research, the multi-heat pipes are designed and analysed with a shell assisted heat exchanger. Influence of triangular baffles were analysed and performance are studied. The inlet parameters of the heat transfer fluids are measured with various mass flow rates and temperature inputs.

\section{FABRICATION AND WORKING PROCESS}

\section{A. Fabrication of setup}

To study the heat transfer characteristics of a MHPIHE is designed by without and with baffles and given in Figure $1 \& 2$. In this work, MHPIHE is fabricated with three heat pipe in which copper as a heat pipe material and Galvanized Iron as shell material for heat exchanger with a diameter of $102 \mathrm{~mm}$ and length of $850 \mathrm{~mm}$ at evaporator zone. Heat pipe inner and outer diameter as 19 and $17 \mathrm{~mm}$ and total length as $1000 \mathrm{~mm}$. Condenser diameter of $35 \mathrm{~mm}$, length as $150 \mathrm{~mm}$ and without adiabatic length. Nine numbers of triangular baffles were used with the size of $60 \times 60 \times 10 \mathrm{~mm}$ were shown in figure $2 \mathrm{a}$.

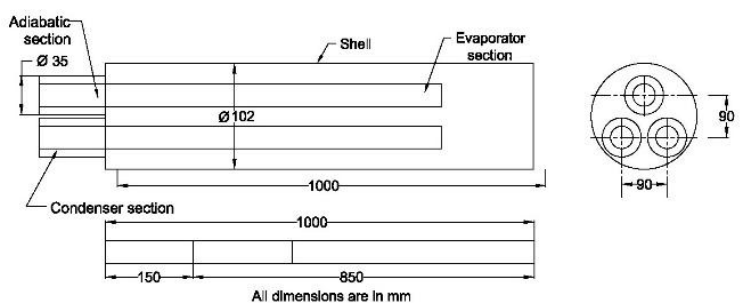

Fig 1. Schematic diagram of a Multi Heat-pipe Heat exchanger without Baffles

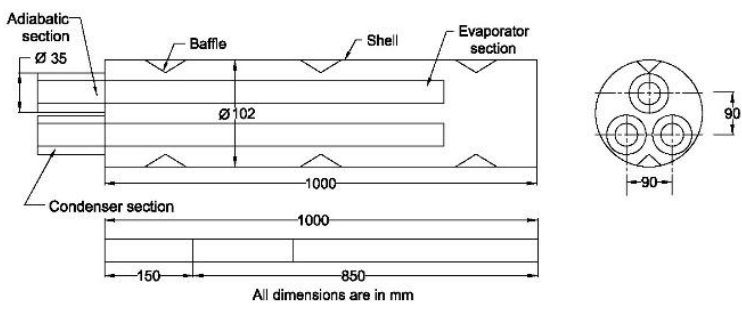

Fig 2. Schematic diagram of a Multi Heat-pipe Heat exchanger with Baffles 


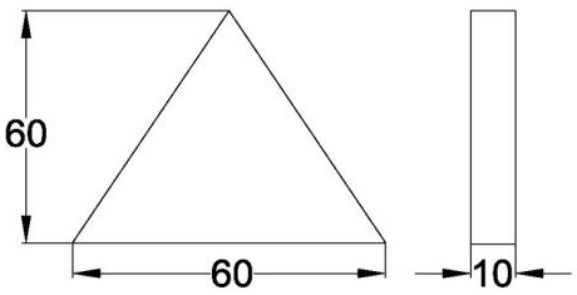

All dimensions are in $\mathrm{mm}$

Fig 2 a. Schematic diagram of a Triangular Baffles

The two water tanks, for hot and cold water with a capacity of five liters. Which contains one coiled immersion electric heater with two Kilowatts and a temperature controller to regulate the temperatures of hot water. The rotameters with a range of three Liter per minute are used to regulate the flow rates of both hot and cold water. Two thermocouples observe the external surface temperatures of the evaporator and condenser regions to measure the temperature interface with the environment. The experimental setup is designed for both without and with baffles are given in figure $3 \& 4$.

Table 1. Thermo-physical properties of Acetone

\begin{tabular}{|l|l|}
\hline Properties & Acetone \\
\hline Boiling point & $56.08^{\circ} \mathrm{C}$ \\
\hline Melting point & $-94.9^{\circ} \mathrm{C}$ \\
\hline $\begin{array}{l}\text { Latent heat of } \\
\text { evaporation }(\lambda)\end{array}$ & $534 \mathrm{~kJ} / \mathrm{kg}$ \\
\hline Density of liquid $\left(\rho_{l}\right)$ & $784.5 \mathrm{~kg} / \mathrm{m}^{3}$ \\
\hline
\end{tabular}

\section{B. Working Process}

At primary test, heat pipes are induced in the heat exchanger without baffles and the secondary test is carried out with nine numbers of triangular baffles. In both the test Acetone is used as working fluid and charged with fill ratios of one hundred percentage, the thermo-physical properties of working fluid are shown in Table 1. The heat transfer fluid is chosen as water for the analysis.

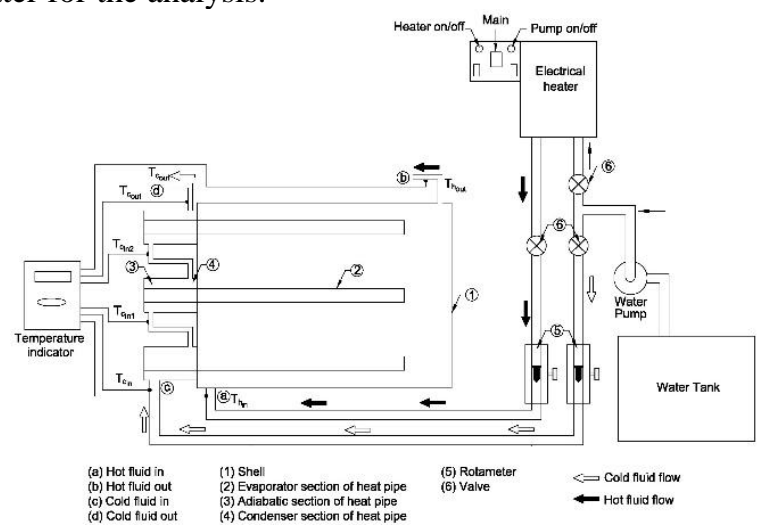

Fig 3. Schematic diagram of an Experimental setup of MHPIHE without Baffles

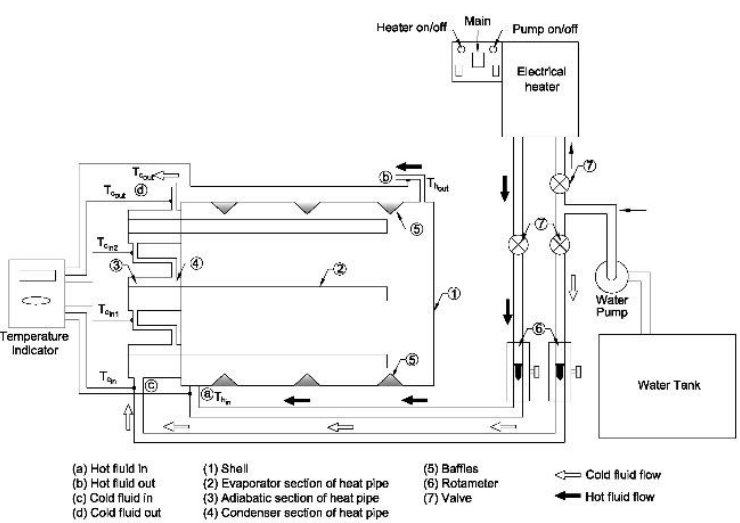

Fig 4. Schematic diagram of an Experimental setup of MHPIHE with Triangular Baffles

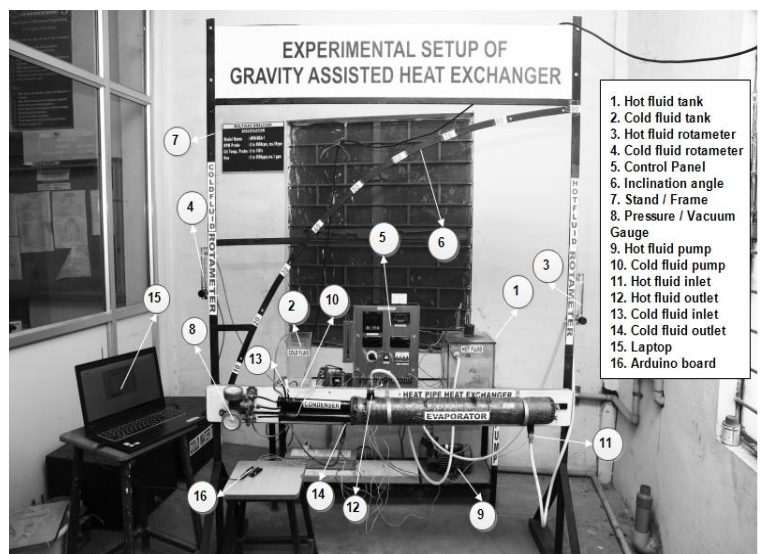

Fig 5. Fabricated experimental setup of the Multi-Heat pipe heat exchanger

At primary stage, MHPIHE is kept at a $0^{\circ}$ tilt angle (horizontal axis) and the WF as acetone and water as HTF as shown in figure 5. In initial stage MHPIHE is fabricated by without baffles. The Hot water mass flow rate and inlet temperature are fixed as $40 \mathrm{LPH}$ and $50{ }^{\circ} \mathrm{C}$. The mass flow rate of cold water and inlet temperature as $20 \mathrm{LPH}$ and $32{ }^{\circ} \mathrm{C}$ as the ambient temperature condition for the analysis. At the evaporator zone of a heat exchanger, hot water exchanges the heat to the acetone in the heat pipe. Thus WF absorbs the heat and latent heat of phase change have occurred. The hot and cold zones mass flow rates are given in LPH such as 60, 80, 100, 120 and 30, 40, 50, 60. Temperatures at an inlet of hot and cold zones are $60^{\circ} \mathrm{C}, 70^{\circ} \mathrm{C}$ and $32^{\circ} \mathrm{C}$. The above similar conditions are repeated for second test rig with the influence of triangular baffles and experimentation is done.

\section{RESULTS AND DISCUSSION}

To investigate the fabricated MHPIHE. The figure 6 predicts the mass flow rate of hot water on effectiveness for both without and with baffles condition. This graph predicts that by using water as HTF and Acetone as WF for the first test is carried out by without baffles condition. The inlet temperatures of the hot water as $50^{\circ} \mathrm{C}$ to $70^{\circ} \mathrm{C}$ and for varying $\mathrm{m}_{\mathrm{hi}}$ from $40 \mathrm{LPH}$ to $120 \mathrm{LPH}$ and $\psi$ as $0^{\circ}$. The maximum effectiveness observed is $39 \%$ at $100 \mathrm{LPH}, \psi$ as $0^{\circ}$ and $60^{\circ} \mathrm{C}$. When the mass flow rate increases by $120 \mathrm{LPH}$ the achieved effectiveness is $32 \%$ for same condition. In the second test, the triangular baffle are used with similar stated condition. In 100 LPH the observed effectiveness is

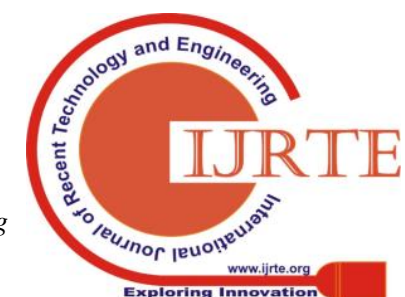


$71 \%$ for $0^{\circ}$. At $120 \mathrm{LPH}$ the achieved effectiveness is $57 \%$ for $0^{\circ}$. In this investigation also similar trends of graphs are predicted for $100 \mathrm{LPH}$ and $120 \mathrm{LPH}$. This shows that both tests of without and with baffles conditions the $100 \mathrm{LPH}$, $60^{\circ} \mathrm{C}$ shows superior results than other temperature and mass flow rate. Similarly while improving the $\mathrm{m}_{\mathrm{hi}}$ from $100 \mathrm{LPH}$ to $120 \mathrm{LPH}$ the same decrement in effectiveness is achieved for both test rigs. This decrement in effectiveness is due to the minimum heat absorption and release capability of the hot and cold fluid at both zones of the heat pipe. The influence of triangular baffles shows increase in effectiveness due to the increase in surface area inside the shell. This increase in surface area leads to the increase in contact area of the heat transfer fluid with the working fluid inside the heat pipe. Thus maximum phase transformation is accrued in the WF. In this analysis above $60^{\circ} \mathrm{C}$ there is maximum heat evolved in the shell so, no phase transformation is occurred inside the heat pipe at the evaporator zone so performance gets reduced when the temperature of HTF increases above the optimum condition. This leads to the improvement in effectiveness is calculated by the equation (1)

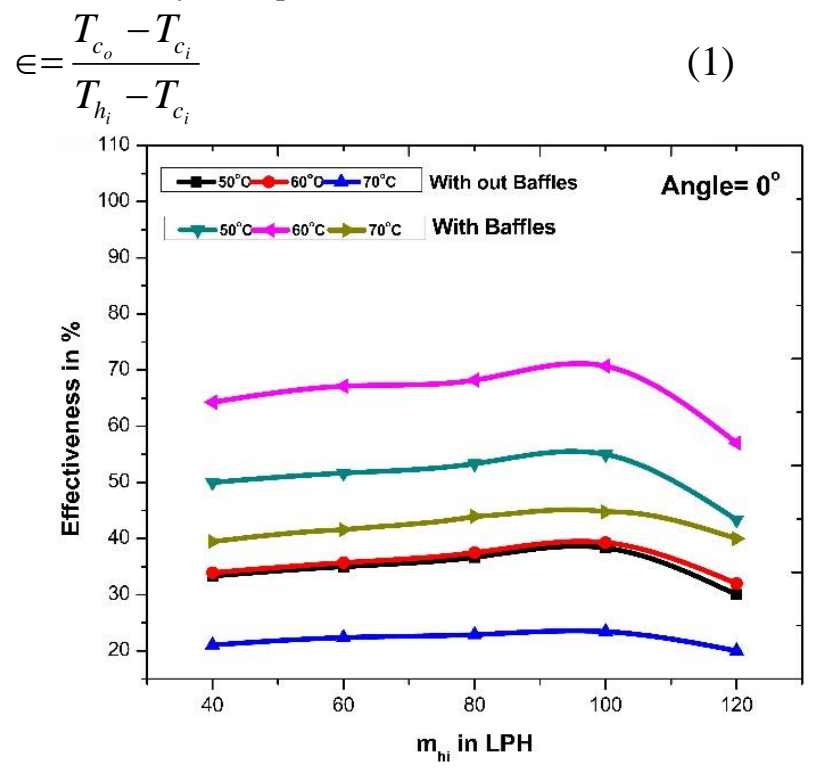

Fig 6 Mass flow rate of hot fluid on Effectiveness

Figure 7 inferred the mass flow rate on heat transfer rate for without and with baffles conditions. The conditions for the observation are $\mathrm{T}_{\mathrm{hi}}$ as $50^{\circ} \mathrm{C}$ to $70^{\circ} \mathrm{C}, \mathrm{m}_{\mathrm{hi}}$ ranges from 40LPH to $120 \mathrm{LPH}$ and the inclination angle of $0^{\circ}$. In the first test, Acetone is used as WF and Water as HTF for without baffle condition. The heat transfer rate $(\mathrm{Q})$ shows increment for $40 \mathrm{LPH}$ to $100 \mathrm{LPH}$ at the range of $209 \mathrm{~W}$ to $576 \mathrm{~W}$ for $\psi$ as $0^{\circ}$ and $60^{\circ} \mathrm{C}$. Similarly, for $120 \mathrm{LPH}$, the Q value is $544 \mathrm{~W}$ for $\psi$ as $0^{\circ}$ and $60^{\circ} \mathrm{C}$. This plots reveals that $100 \mathrm{LPH}$ shows highest heat transfer rate in the system. In the second test, for with triangular baffle condition. The similar type of trends are achieved. The heat transfer rate $(\mathrm{Q})$ shows increment for 40 LPH to $100 \mathrm{LPH}$ at the range of $419 \mathrm{~W}$ to $1151 \mathrm{~W}$ for $\psi$ as $0^{\circ}$ and $60^{\circ} \mathrm{C}$. Similarly, for $120 \mathrm{LPH}$, the Q value is $1116 \mathrm{~W}$ for $\psi$ as $0^{\circ}$ and $60^{\circ} \mathrm{C}$. This observation also reveals the same results at $100 \mathrm{LPH}$ maximum (Q) values are achieved than $120 \mathrm{LPH}$. In both the investigations at $100 \mathrm{LPH}, \psi$ as $0^{\circ}$ and $60^{\circ} \mathrm{C}$ has highest results, but by comparing both the conditions of with and without baffles, with baffles shows superior result. This increase in heat transfer rate is achieved by the maximum absorption of heat energy by the cold fluid at the condenser zone. When the hot fluid inlet temperature at $60^{\circ} \mathrm{C}$ there is

maximum heat transfer happens between HTF and working fluids at the evaporator zone. Hence, the heat transfer rate is calculated using below formula (2) and (3)

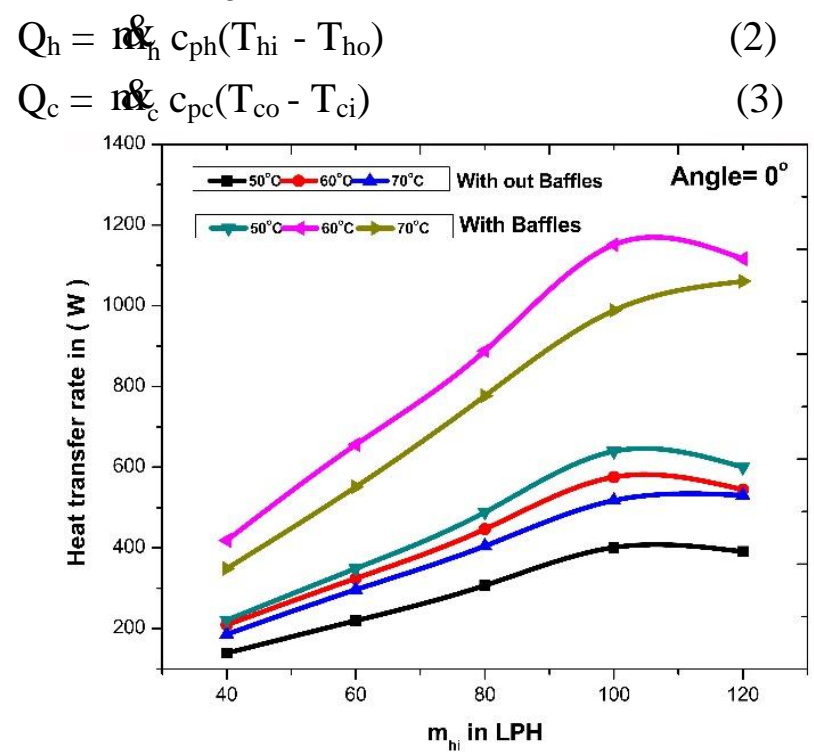

Fig 7 Mass flow rate on Heat transfer rate

Figure 8 shows that mass flow rate on heat transfer coefficient with water as HTF for both without and with baffles conditions. The conditions for observation are $\mathrm{T}_{\mathrm{hi}}$ as $50^{\circ} \mathrm{C}$ to $70^{\circ} \mathrm{C}, \mathrm{m}_{\mathrm{hi}}$ from $40 \mathrm{LPH}$ to $120 \mathrm{LPH}$, inclination angle of $0^{\circ}$ and without baffle condition. The observed heat transfer coefficient (h) at $40 \mathrm{LPH}$ to $100 \mathrm{LPH}$ for $\psi$ as $0^{\circ}$ and $60^{\circ} \mathrm{C}$ is $320 \mathrm{~W} / \mathrm{m}^{2}{ }^{\circ} \mathrm{C}$ to $989 \mathrm{~W} / \mathrm{m}^{2}{ }^{\circ} \mathrm{C}$. At $120 \mathrm{LPH}, \psi$ as $0^{\circ}$ and $60^{\circ} \mathrm{C}$ the observed value is $899 \mathrm{~W} / \mathrm{m}^{2}{ }^{\circ} \mathrm{C}$. In with triangular baffles the similar value of trends is observed. At $40 \mathrm{LPH}$ to $100 \mathrm{LPH}$ the observed $(\mathrm{h})$ value ranges as $845 \mathrm{~W} / \mathrm{m}^{2}{ }^{\circ} \mathrm{C}$ to $2594 \mathrm{~W} / \mathrm{m}^{2}$ ${ }^{\circ} \mathrm{C}$ for $\psi$ as $0^{\circ}$ and $60^{\circ} \mathrm{C}$. Similarly for $120 \mathrm{LPH}$ the observed (h) as $2105 \mathrm{~W} / \mathrm{m}^{2}{ }^{\circ} \mathrm{C}$ for $\psi$ as $0^{\circ}$ and $60^{\circ} \mathrm{C}$. In both with and without baffles shows similar trends in the investigation at $100 \mathrm{LPH}$ highest value of (h) is achieved than $120 \mathrm{LPH}$ While considering the both tests with baffles shows highest heat transfer coefficient. Using the below equation the convective heat transfer coefficient of cold fluid on MHPIHE is analysed by the equation (4)

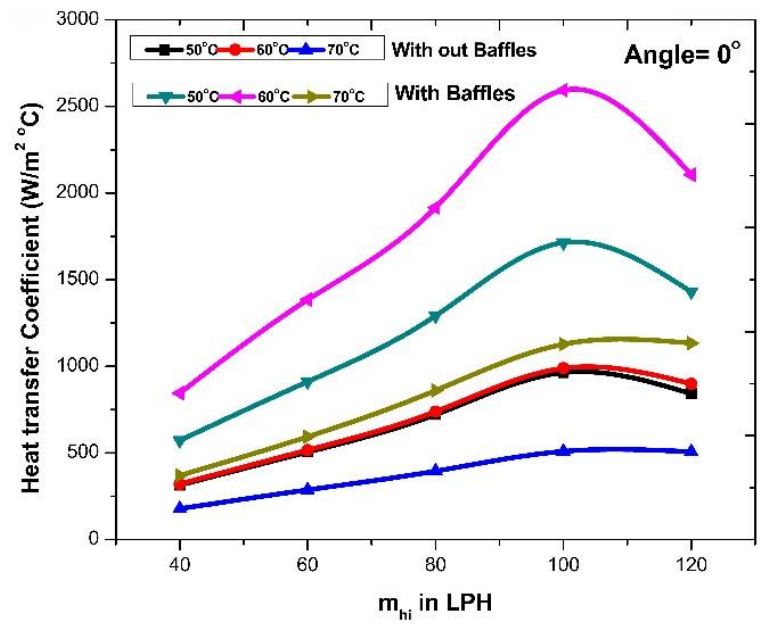

Fig 8 Mass flow rate on heat transfer coefficient 
$\mathrm{h}=\frac{Q c}{A *(\Delta T)_{l m}}$

In comparing the both test rigs. This predicts the higher heat transfer coefficient at hot fluid for $100 \mathrm{LPH}$ and $60^{\circ} \mathrm{C}$ with the $0^{\circ}$ inclination angle for acetone as WF. This is due to the higher release of sensible heat to the cold fluid, by the working fluids which lead to maximum heat transfer along the system.

\section{CONCLUSION}

- It is inferred that optimum conditions observed from the investigation are hot fluid mass flow rates $\left(\mathrm{m}_{\mathrm{hi}}\right)$ as $100 \mathrm{LPH}$ and cold fluid $\left(\mathrm{m}_{\mathrm{ci}}\right)$ as $50 \mathrm{LPH}$, hot fluid at an inlet temperature $\left(\mathrm{T}_{\mathrm{hi}}\right)$ as $60^{\circ} \mathrm{C}$, the inclination angle $(\psi)$ as $0^{\circ}$ (Horizontal axis) for with triangular baffles.

- While comparing both conditions of with and without baffles for above-revealed conditions, with triangular baffles shows maximum results when comparing to without baffles. There is an increment in results of $82.05 \%$ for effectiveness, $98.92 \%$ for heat transfer rate, $162.28 \%$ for heat transfer coefficient are achieved.

- This investigation reveals that Multi heat pipe induced in the heat exchanger with triangular baffles shows superior in results, while comparing to without baffles in all the observed conditions of the investigation.

\section{APPENDIX}

\section{Nomenclature}

A - Area of heat transfer $\left(\mathrm{m}^{2}\right)$

C - Heat capacity rate $(\mathrm{kW} / \mathrm{K})$

$\mathrm{C}_{\mathrm{p}}$ - Specific heat of the fluid $(\mathrm{kJ} / \mathrm{kg} \mathrm{K})$

D - Diameter (m)

h - Heat transfer coefficient $\left(\mathrm{W} / \mathrm{m}^{2}{ }^{\circ} \mathrm{C}\right)$

L - Length (mm)

$\mathrm{m}$ - Mass flow rate of fluid (LPH)

$\mathrm{Q}$ - Heat transfer rate (W)

\section{Abbreviations}

MHPIHE - Multi Heat Pipe Induced Heat exchanger

HTF - Heat Transfer Fluid

LPM - Liter Per Minute

WF - Working Fluid

\section{Greek Letters}

$(\Delta \mathrm{T})_{\operatorname{lm}} \quad-$ Log mean temperature difference, $\left({ }^{\circ} \mathrm{C}\right)$

$\in \quad-$ Effectiveness, $(\%)$

$\psi \quad-$ Tilt angle / Inclination angle, $\left({ }^{\circ}\right)$

\section{REFERENCES}

1. Said Salem. A, Bilal Akash. A, "Experimental performance of a heat pipe," International Communication of Heat and Mass Transfer. 1999, 26 (5), pp. 679-684

2. Ișık H.G, Ömür. C, Uygur.A.B, Horuz. I, "A novel burst test approach for the qualification of heat pipes developed for space applications," International Journal of Pressure Vessels and Piping, 2018, 165, pp. 241-248

3. Alicetin Gurses, Cannistrano. C, "The inclination effect on the performance of water-filled heat pipes," Renewable Energy, 1991, 1, pp. 667-674

4. Esarte. J, Domiguez. M, "Experimental analysis of a flat heat-pipe working against gravity," Applied Thermal Engineering, 2003, 23,pp. 1619-1627

5. Khalid Joudi. A, Witwit. A. M, "Improvements of gravity assisted wickless heat pipes," Energy Conversion and Management, 2000, 41, pp. 2041-2061

6. Hossain. R.A, M.A.K. Chowdhuri, M.A.K, Feroz. C.M, "Design fabrication and experimental study of heat transfer characteristics of a Micro Heat Pipe," Jordan Journal of Mechanical and Industrial Engineering, 2010, 4, pp. 531-542

7. Didi Zhang, Gang Li, Yuging Liu, Xialiang Tian, "Simulation and experimental studies of R134a flow condensation in a pump assisted separate heat pipe," International Journal of heat and mass transfer, 2018, 126, pp. 1020-1030

8. Lydia Wermer. R, Martin Ward. J, Justin Simpson. D, Robert Zimmerman. A, James Stewart. A, "A high capacity self priming counter gravity heat pipe," International Journal of Heat and Mass Transfer, 2018, 125, pp. 1369-1378

9. Luis Diego Fonseca, John, Franklin Miller, "Result of a three evaporator in cryogenic helium heat pipe," International Journal of Heat and Mass Transfer, 2018, 120, pp. 1275-1286

10. Shabgard. H, Bergman. T.L, Shariti. N, Faghri. A, "High temperature latent heat thermal energy storage using heat pipes,' International Journal of Heat and Mass Transfer, 2010, 53, pp 2979-2988

11. Kempers. R, Ewing. D, Ching. C. Y, "Effect of number of mesh layers and fluid loading on the performance of screen mesh wicked heat pipes," Applied Thermal Engineering, 2006, 26, pp. 89-595

12. Shafai. M, Blanoco. V, Vafai. K, and Manco. O, "An investigation of the thermal performance of cylindrical heat pipes using nanofluid," International Journal of Heat and Mass Transfer, 2010, 53, pp 376-383

13. Pis mennyi. E.N, Khayrnasov. S.M, Rassamakin. B.M, "Heat transfer in evaporation zone of aluminium grooved heat pipes, International journal of Heat and Mass Transfer, 2018, 127, pp. 80-88

14. Durga Bastakoti, Hongna Zhang, WeihuaCai, Fengchen Li, “An experimental investigation of thermal performance of pulsating heat pipe with alcohols and surfactant solutions," International Journal of Heat and Mass Transfer, 2018, 117, pp. 1032-1040

15. Vivek Patel. K, “An efficient optimization and comparative analysis of ammonia and methanol heat pipe for satellite application," Energy conversion and Management, 2018, 165, pp. 382-395

\section{AUTHORS PROFILE}

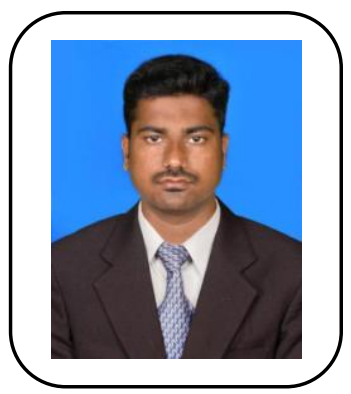

Mr. P.Ramkumar, Assistant Professor in Mechanical Engineering at Kalasalingam University. I have completed B.E (Mechanical Engineering), M.E (Thermal Power Engineering), pursuing $\mathrm{Ph} . \mathrm{D}$. (Thermal Engineering) having five years of teaching experience for U.G and P.G students. I am life time member of Indian Society of Heat and Mass Transfer (ISHMT - IIT Madras). I have published two papers in International journal, three papers published in International conference and four papers in National conference. I am doing my research in the field of heat pipe and compact heat exchanger. 


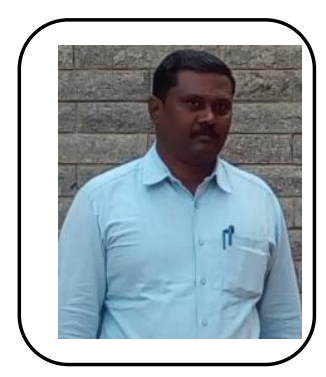

Dr. M. Sivasubramanian, Associate Professor in Automobile Engineering at Kalasalingam University. I have completed $\mathrm{Ph} . \mathrm{D}$ in thermal engineering, I am having twenty years of teaching experience. I am life time member of Indian Society of Heat and Mass Transfer (ISHMT - IIT Madras), MISTE, SAE. Seven papers in International journal and twenty five papers in International / National conference. Research area in the fluid flow.

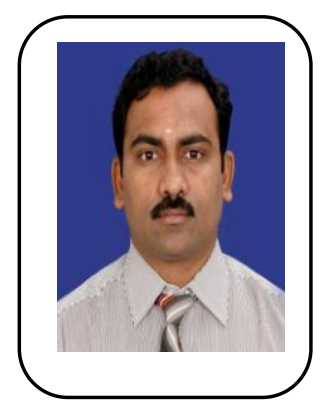

Dr. P. Rajesh Kanna, Professor in Mechanical Engineering at Al Ghurair University, Dubai, United Arab Emirates. I have completed in Ph.D in IIT - Guwahati. Post Doc at National Taiwan University of Science and Technology, Department of Mechanical Engineering, CFD, Taiwan, Taipei. Research expert in experimentation and numerical analysis in heat transfer, fluid mechanics, CFD. His h-index is 16 , i-10-index is 21 , and Citation Statistics is 611 .

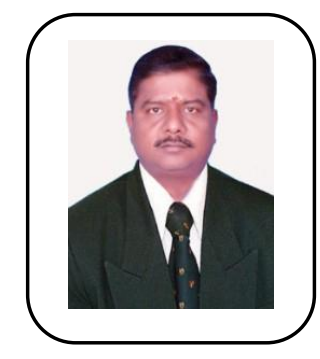

Dr. P. Raveendiran, Associate Professor at Alagappa Chettiar Government College of Engineering and Technology, Alagappa University, Karaikudi. Ph.D has been completed in Annamalai University. I have published Eight International journal, one national journal, and two national / international conferences. One book published in heat and mass transfer. I am having teaching experience of seventeen years. I am expertise in the field of Heat pipe, Heat exchanger. 